УДК 622.24.063.2

\title{
ИССЛЕДОВАНИЕ ВЛИЯНИЯ ФОРМИАТА НАТРИЯ НА ТЕРМОСТОЙКОСТЬ КРАХМАЛСОДЕРЖАЩЕГО ГЛИНИСТОГО БУРОВОГО РАСТВОРА
}

\author{
Конесев Геннадий Васильевич1, \\ KonesevGV@mail.ru
}

Ахаев Рустам Радикович1,
unixru@mail.ru

Дихтярь Татьяна Дмитриевна², dihttd@gmail.com

\author{
Мамаева Оксана Георгиевна', \\ oxana.mamaeva2013@yandex.ru \\ Вязниковцев Сергей Федорович 1 , \\ kontakt-sintez@yandex.ru \\ 1 Уфимский государственный нефртяной технический университет, \\ Россия, 450062, г. Уфа, ул. Космонавтов, 1. \\ 2 Филиал Уфимского государственного нефтяного технического университета в г. Октябрьском, \\ Россия, 452620, г. Октябрьский, ул. Девонская, 54.
}

Актуальность работы обусловлена необходимостью сохранения свойств буровых растворов, содержащих крахмальные реагенты, в условиях высокой минерализации и длительного воздействия повышенных температур.

Цель: экспериментально определить температурный интервал и оптимальные концентрации эфффективного применения формиата натрия в составе буровых растворов, содержащих крахмальные реагенты.

объекты: крахмалсодержащий әлинистый буровой раствор с разными концентрациями натриевых солей (хлорида натрия и формиата натрия).

Методы: определение фильтрационных и реологических параметров согласно ГОСT 33213-2014 (ISO 10414-1:2008) после старения буровых растворов при повышенных температурах с использованием термоячеек; проведение опытов методом построения матрицы центрального композиционного планирования и математической обработки результатов экспериментальных данных.

Результаты. Проведен сравнительный анализ свойств глинистых буровых растворов, содержащих крахмальный реагент, с использованием хлорида натрия $\mathrm{NaCl}$ и формиата натрия $\mathrm{HCOONa}$, после длительного нахождения системы в условиях высоких температур. Показано, что природа соли оказывает значительное влияние на термостойкость крахмалсодержащего бурового раствора: хлорид натрия не обеспечивает термостабильности раствора; формиат натрия позволяет обеспечить термостойкость крахмалсодержащего бурового раствора до $140-160{ }^{\circ} \mathrm{C}$. Получены уравнения регрессии второго порядка, описывающие зависимость показателя фильтрации и реологических параметров крахмалсодержащего глинистого бурового раствора от температуры и концентрации формиата натрия. Установлено, что термостойкость крахмального реагента при совместном применении с формиатом натрия повышается вследствие высокой растворимости соли, которая подавляет гидратацию полисахарида и, соответственно, замедляет его гидролиз при воздействии высоких температур. Выявлено, что эфрфективная концентрация натриевой соли муравьиной кислоты как термостабилизатора в составе крахмалсодержащего бурового раствора зависит от температуры применения системы: при низких концентрациях соли термостойкость обеспечивается в диапазоне $100-133^{\circ} \mathrm{C}$ за счет хорошей активности крахмала; при высоких концентрациях соли - в диапазоне $133-160{ }^{\circ} \mathrm{C}$ - за счет низкого содержания свободной воды в системе вследствие высокой растворимости формиата натрия. Показано, что формиат натрия не предотвращает набухание глин, а наоборот, способен оказьвать на них пептизирующее действие.

\section{Ключевые слова:}

Полисахарид, деструкция, термостойкость, минерализация, формиат, буровой раствор, соль, крахмал.

\section{Введение}

Для бурения мощных толщ галитовых отложений в условиях высоких пластовых давлений и температур требуются соленасыщенные утяжеленные термостойкие буровые растворы. В качестве соли в составе этих буровых растворов чаще всего используют хлористый натрий, а регулятором фильтрации выступают крахмальные реагенты. Однако применение последних ограничивается их термостойкостью $\left(121{ }^{\circ} \mathrm{C}\right)$. Попытки многих исследователей повысить устойчи- вость полисахарида к высоким температурам оказались успешными только в составе пресных растворов за счет дополнительного введения термостабилизирующих добавок [1-6]; при использовании же буровых растворов, насыщенных хлористым натрием, обеспечить термостойкость крахмальных реагентов выше $120{ }^{\circ} \mathrm{C}$ до сих пор не удалось [3-5].

Сегодня в России и за рубежом широкую популярность приобретают растворы на основе солей муравьиной кислоты (формиатов), которые обеспечива- 
ют стабильность в условиях высоких температур таких полисахаридов, как ксантан [7, 8], полианионная целлюлоза [8, 9], карбоксиметилцеллюлоза [10], либо полисахаридных композиций, содержащих одновременно ПАЦ и крахмал $[11,12]$, ксантан и крахмал $[13,14]$.

Данных о непосредственном влиянии формиатов на термостойкость крахмальных реагентов нет; кроме того, в научных публикациях отсутствует сравнение их эффективности с хлоридом натрия, традиционно применяемым в соленасыщенных растворах. Предварительные лабораторные испытания также показали противоречивые результаты - в каких-то случаях соли муравьиной кислоты обеспечивают устойчивость к высоким температурам крахмалсодержащих растворов, а в каких-то, наоборот, ухудшают, даже при температурах ниже $120{ }^{\circ} \mathrm{C}$. Все это потребовало тщательного изучения влияния формиатов на термостойкость крахмальных реагентов.

Необходимость проведения таких исследований дополнительно обусловлена перспективностью применения формиатов для бурения соляных пород - изза высокой растворимости в воде они намного эффективней, чем хлористый натрий, могут подавлять растворимость галитовых отложений, а также дадут возможность получать растворы высоких плотностей с более низким содержанием твердой фазы (табл. 1).

Таблица 1. Предельная растворимость в воде солей $и$ максимально возможная плотность водных растворов [15]

Table 1. Solubility of salts in water and the highest possible density of brines [15]

\begin{tabular}{|l|c|c|}
\hline $\begin{array}{c}\text { Название соли } \\
\text { Name of salt }\end{array}$ & $\begin{array}{c}\text { Растворимость в воде } \\
\text { при температуре } \\
20^{\circ} \mathrm{C}, \text { г } / 100 \text { г воды } \\
\text { Solubility in water at } 20 \\
{ }^{\circ} \mathrm{C}, \mathrm{g} / 100 \mathrm{~g} \text { of water }\end{array}$ & $\begin{array}{c}\text { Максимально } \\
\text { возможная плотность } \\
\text { раствора, кг/ } \mathrm{m}^{3} \\
\text { Highest possible density } \\
\text { of the solution, } \mathrm{kg} / \mathrm{m}^{3}\end{array}$ \\
\hline $\begin{array}{l}\text { Хлорид натрия } \\
\text { Sodium chloride }\end{array}$ & 35,9 & 1197 \\
\hline $\begin{array}{l}\text { Формиат натрия } \\
\text { Sodium formate }\end{array}$ & 97,2 & 1330 \\
\hline $\begin{array}{l}\text { Формиат калия } \\
\text { Potassium } \\
\text { formate }\end{array}$ & 337,0 & 1590 \\
\hline $\begin{array}{l}\text { Формиат цезия } \\
\text { Cesium formate }\end{array}$ & 446,0 & 2300 \\
\hline
\end{tabular}

Влияние типа соли на свойства крахмалсодержащего бурового раствора, находящегося в условия длительного воздействия повышенных температур

Эффективное влияние формиатов на термостойкость полисахаридов исследователи объясняют высокой растворимостью солей [16], повышенными значениями $\mathrm{pH}$ [15], низкой активностью микроорганизмов [17].

При насыщении буровых промывочных жидкостей хлористым натрием, за исключением нейтральных значений $\mathrm{pH}$, также снижается активность воды и практически прекращается деятельность микроорганизмов. Однако устойчивость полисахаридов к воздействию высоких температур в присутствии этой соли более низкая.
Для того чтобы убедиться, что на термостойкость крахмалсодержащего бурового раствора оказывает влияние не только степень минерализации, но и тип соли, в качестве объектов исследования были выбраны две соли с одинаковым катионом и разными анионами - традиционно используемый хлорид натрия и потенциально перспективный формиат натрия. Различие в анионах влияет не только на степень их растворимости, но и способствует тому, что каждая соль создает свой рН водной среды, имеющий огромное значение в системах буровых растворов.

Натрий хлористый $\mathrm{NaCl}$ - соль сильного основания и сильной кислоты, вследствие чего не подвергается гидролизу и $\mathrm{pH}$ среды нейтральный ( $\mathrm{pH} 7$ ); формиат натрия HCOONa - соль сильного основания и слабой кислоты, поэтому гидролизуется по анионному типу, в результате чего образуются гидроксидионы $\left(\mathrm{OH}^{-}\right)$и $\mathrm{pH}$ среды имеет щелочную реакцию $(\mathrm{pH}>7)$.

Гидролиз соли - процесс равновесный, поэтому постоянное наличие гидрокисид-ионов в дисперсионной среде бурового раствора, в состав которого входит формиат натрия, будет способствовать образованию буферной системы со стабильным значением $\mathrm{pH}$ в интервале 8-10 [18]. Следовательно, формиат натрия, в отличие от хлорида натрия, не должен обладать ингибирующим действием по отношению к глине, а даже, наоборот, в какой-то степени может способствовать ее пептизации. Стабильное присутствие гидроксильных ионов в дисперсионной среде бурового раствора должно оказывать благоприятное влияние на крахмальный полисахарид при повышенных температурах - предотвращается снижение $\mathrm{pH}$ до диапазона, в котором может произойти кислотный гидролиз [15].

Таблица 2. Состав базового глинистого крахмалсодержащего бурового раствора

Table 2. Composition of the basic clay starch-containing drilling mud

\begin{tabular}{|c|c|c|}
\hline $\begin{array}{l}\text { Наименование } \\
\text { реагента } \\
\text { Reagent name }\end{array}$ & Назначение/Purpose & $\begin{array}{l}\text { Концентрация, } \\
\text { мас. \% } \\
\text { Concentration, } \\
\text { wt. \% }\end{array}$ \\
\hline Дарсан/Darsan & Бактерицид/Bactericide & 0,1 \\
\hline $\mathrm{NaOH}$ & Регулятор $\mathrm{pH} / \mathrm{pH}$ regulator & 0,3 \\
\hline $\begin{array}{l}\text { ПБМА } \\
\text { РВМА }\end{array}$ & $\begin{array}{l}\text { Дисперсная фаза; } \\
\text { структурообразователь } \\
\text { Dispersed phase; builder }\end{array}$ & 4 \\
\hline $\begin{array}{l}\text { Сульфирован- } \\
\text { ный битум } \\
\text { Sulphonated } \\
\text { bitumen }\end{array}$ & $\begin{array}{l}\text { Стабилизатор глинистой } \\
\text { суспензии } \\
\text { Clay slurry stabilizer }\end{array}$ & 1,9 \\
\hline $\begin{array}{l}\text { Крахмал } \\
\text { «НД-техник» } \\
\text { Starch «ND- } \\
\text { technician» }\end{array}$ & $\begin{array}{l}\text { Понизитель фильтрации } \\
\text { Filtration reducer }\end{array}$ & 2 \\
\hline Мел/Chalk & $\begin{array}{l}\text { Кольматант, утяжелитель } \\
\text { Colmatant, weighting compound }\end{array}$ & 8 \\
\hline
\end{tabular}

Исследуемая соль добавлялась в определенной концентрации к базовому глинистому крахмалсодержащему буровому раствору (табл. 2), после чего он заливался в термоячейки и подвергался старению при 
температуре $160{ }^{\circ} \mathrm{C}$ в течение 32 часов. По истечении заданного времени извлеченный из ячейки буровой раствор перемешивали и определяли его технологические параметры в соответствии с ГОСТ 33213-2014 (ISO 10414-1:2008) [19]. Аналогичные операции также были проведены с базовым глинистым буровым раствором. Результаты экспериментальных исследований представлены в табл. 3.

Таблица 3. Технологические параметры базового и с добавлением соли крахмал-содержащего глинистого бурового раствора после 32 часов термостатирования при температуре $160^{\circ} \mathrm{C}$

Table 3. Technological parameters of the base and with the addition of salt starch-containing clay drilling mud after 32 hours of thermostating at $160{ }^{\circ} \mathrm{C}$

\begin{tabular}{|c|c|c|c|c|c|c|}
\hline $\begin{array}{c}\text { Раствор } \\
\text { Drilling fluid/mud }\end{array}$ & 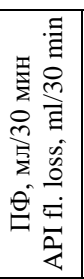 & 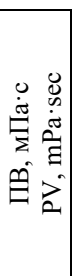 & 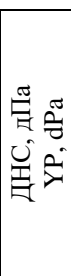 & 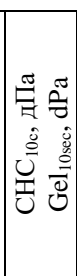 & 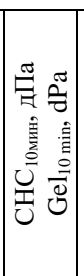 & I \\
\hline $\begin{array}{l}\text { Базовый раствор (Б.Р.) } \\
\text { Base mud (В.М.) }\end{array}$ & 8 & 7 & 38 & 17 & 45 & 8,8 \\
\hline $\begin{array}{l}\text { Б.P. }+8,98 \% \mathrm{NaCl} \\
\text { B.M. }+8,98 \% \mathrm{NaCl}\end{array}$ & 10 & 6,6 & 28 & 6 & 12 & 7,8 \\
\hline $\begin{array}{l}\text { E.P.+17,95\% NaCl } \\
\text { B.M.+17,95\% NaCl }\end{array}$ & 16 & 10,1 & 21 & 3 & 7 & 7,5 \\
\hline $\begin{array}{l}\text { E.P. }+35,9 \% \mathrm{NaCl} \\
\text { B.M. }+35,9 \% \mathrm{NaCl}\end{array}$ & 17 & 12,5 & 2,9 & 1,2 & 1,8 & 7,3 \\
\hline $\begin{array}{l}\text { Б.P. }+24,3 \% \text { HCOONa } \\
\text { B.M. }+24,3 \% \text { HCOONa }\end{array}$ & 18 & 12,6 & 38 & 22 & 28 & 9,5 \\
\hline $\begin{array}{l}\text { Б.P. }+48,6 \% \text { HCOONa } \\
\text { B.M. }+48,6 \% \text { HCOONa }\end{array}$ & 19 & 24,3 & 42 & 19 & 23 & 9,6 \\
\hline $\begin{array}{l}\text { Б.P.+97,2 \% HCOONa } \\
\text { B.M. }+97,2 \% \text { HCOONa }\end{array}$ & 8 & 33,7 & 53 & 18 & 22 & 9,6 \\
\hline
\end{tabular}

Анализ данных, представленных в табл. 3, показывает, что увеличение концентрации хлорида натрия в составе бурового раствора ведет к росту показателя фильтрации и снижению реологических параметров, характеризующих структурно-механические свойства буровых растворов (ДНС и СНС), что обусловлено коагулирующим действием соли по отношению к глине. При этом значения показателей фильтрации при 17,95 и $35,9 \% \mathrm{NaCl}$ практически сопоставимы, хотя при средней концентрации соли полной коагуляции глины еще не наблюдается. Следовательно, максимально возможный показатель фильтрации крахмалсодержащего бурового раствора, в случае применения хлорида натрия, обусловлен полной деструкцией полисахарида при $160^{\circ} \mathrm{C}$.

Неоднозначно влияние на технологические параметры формиата натрия. При минимальной и средней концентрации соли показатель фильтрации имеет достаточно высокие значения, а при максимальной концентрации - значение показателя фильтрации такое же, как у базового пресного раствора. Отсюда возникает вопрос, либо при данной температуре $\left(160{ }^{\circ} \mathrm{C}\right) 24,3$ и 48,6 \% формиата натрия недостаточно для обеспечения термостойкости бурового раствора, содержащего крахмальный полисахарид, либо данная температура слишком высока для этих концентраций и область их эффективного воздействия находится в интервале более низких значений.

Увеличение концентрации формиата натрия в составе крахмалсодержащего бурового раствора ведет к росту ДНС и незначительному снижению СНС, при этом значения СНC, измеренные через 10 с и 10 мин нахождения в покое технологической жидкости, достаточно близки, что напоминает поведение безглинистых биополимерных буровых растворов на основе ксантановой смолы с быстроформирующейся структурой.

Если предположить, что под действием соли муравьиной кислоты действительно идет пептизация глины, то с увеличением концентрации формиата натрия происходил бы рост не только ДНС, но и СНС, при этом значения СНС имели бы прогрессирующий характер во времени как у базового раствора; показатель фильтрации вследствие пептизации глины с увеличением концентрации формиата натрия должен был бы снижаться. Однако данных явлений мы не наблюдаем.

Если допустить, что увеличение пластической вязкости при добавлении солей в обоих случаях обусловлено в основном повышением вязкости дисперсионной среды, то существенное влияние формиата натрия на реологические параметры крахмалсодержащего бурового раствора (ДНС и СНС) при температуре испытания, возможно, связано с особенностями взаимодействия при повышенных температурах крахмального полисахарида с формиатом натрия - либо изменяются внутри- и межмолекулярные водородные связи между полимерными цепями в присутствии соли муравьиной кислоты, либо происходит химическое взаимодействие полисахарида с формиатом натрия (например, сшивка полимерных цепей или продуктов термодеструкции формиатионом).

Таким образом, на основании проведенных исследований, мы можем заключить, что природа соли, добавляемой к крахмалсодержащему глинистому буровому раствору, оказывает значительное влияние на его свойства при воздействии повышенных температур; формиат натрия, в отличие от хлорида натрия, не обладает коагулирующим действием по отношению к глине и при максимальной концентрации (97,2 \%) может обеспечить стабильность раствора до $160{ }^{\circ} \mathrm{C}$ включительно.

\section{Влияние концентрации формиата натрия и температуры на свойства крахмалсодержащего бурового раствора}

Неоднозначное влияние натриевой соли муравьиной кислоты на свойства крахмалсодержащего бурового раствора при воздействии высоких температур потребовало проведения исследований, направленных на определение оптимальных концентраций формиата натрия и рабочих интервалов температур, при которых данная соль будет эффективно обеспечивать термостойкость крахмального полисахарида. 
Для проведения исследований был выбран базовый глинистый буровой раствор, состав которого и назначение каждого компонента представлены в табл. 4. Выбор глины в качестве структурообразователя, так же как и в предыдущем случае (табл. 2), обусловлен исключением из состава другого полисахарида, а именно ксантана.

Таблица 4. Состав базового глинистого крахмалсодержащего бурового раствора

Table 4. Composition of the basic clay starch-containing drilling fluid

\begin{tabular}{|l|l|c|}
\hline $\begin{array}{c}\text { Наименование } \\
\text { реагента } \\
\text { Reagent name }\end{array}$ & \multicolumn{1}{|c|}{$\begin{array}{c}\text { Назначение } \\
\text { Рurpose }\end{array}$} & $\begin{array}{c}\text { Концентра- } \\
\text { ция, мас. \% } \\
\text { Concentration, } \\
\text { wt.\% }\end{array}$ \\
\hline Дарсан/Darsan & Бактерицид/Bactericide & 0,1 \\
\hline $\mathrm{NaOH}$ & Регулятор pH/pH regulator & 0,3 \\
\hline $\begin{array}{l}\text { ПБМА } \\
\text { РВМА }\end{array}$ & $\begin{array}{l}\text { Дисперсная фаза; } \\
\text { структурообразователь } \\
\text { Dispersed phase; builder }\end{array}$ & 4 \\
\hline $\begin{array}{l}\text { Крахмал } \\
\text { «НД-техник» } \\
\text { Starch } \\
\text { «ND-technician» }\end{array}$ & $\begin{array}{l}\text { Понизитель фильтрации } \\
\text { Filtration reducer }\end{array}$ & 2 \\
\hline Мел/Chalk & $\begin{array}{l}\text { Кольматант, утяжелитель } \\
\text { Соlтаtant, wеighting сотроиnd }\end{array}$ & 8 \\
\hline
\end{tabular}

Реализацию этих исследований осуществляли с привлечением программного обеспечения «Statistica» для построения матрицы центрального композиционного планирования эксперимента[20], в котором варьируемыми факторами являлись концентрация соли и температура. Показатель фильтрации глинистого крахмалсодержащего бурового раствора изучался в интервале температур $25-160{ }^{\circ} \mathrm{C}$, а реологические параметры - в интервале 100-160 ${ }^{\circ} \mathrm{C}$ (выбор этих диапазонов температур, как существенно влияемых на исследуемые свойства, - следствие анализа полученных математических моделей на основании экспериментальных данных). Значения варьируемых факторов представлены в табл. 5; матрица планирования эксперимента с результатами выходных значений показателя фильтрации - в табл. 6, а реологических параметров - в табл. 7.

В ходе проведения эксперимента формиат натрия в определенной концентрации, согласно матрице планирования эксперимента, добавлялся к базовому глинистому крахмалсодержащему буровому раствору (табл. 4), который затем заливался в термоячейки и подвергался старению при заданной температуре в течение 16 часов. По истечении установленного времени извлеченный из ячейки буровой раствор перемешивали и определяли его технологические параметры в соответствии с ГОСТ 33213-2014 (ISO 10414-1:2008) [19].

По результатам серии экспериментов, представленных в табл. 6, 7, с помощью модуля «Анализ экспериментальных данных плана» ПО «Statistica» получены математические модели зависимости показателя фильтрации и реологических параметров от концентрации формиата натрия и температуры в виде уравнений регрессий второго порядка с действительными значениями коэффициентов:

$$
\begin{gathered}
\text { П = 15,78255+0,20246 } \cdot \mathrm{x}_{1}-0,29699 \cdot \mathrm{x}_{2} \\
-0,00152 \cdot \mathrm{x}_{1} \cdot \mathrm{x}_{2}+0,00159 \cdot \mathrm{x}_{2}^{2} \\
\text { ПВ }=58,64093-2,9752 \cdot \mathrm{x}_{1}+0,00924 \\
\cdot \mathrm{x}_{1}^{2}-0,00346 \cdot \mathrm{x}_{2}^{2}+0,02644 \cdot \mathrm{x}_{1} \cdot \mathrm{x}_{2} \\
-6,332 \cdot 10^{-7} \cdot \mathrm{x}_{1}^{2} \cdot \mathrm{x}_{2}^{2} \\
\text { ДНС }=-1308,74+21,79 \cdot \mathrm{x}_{2}-0,08 \cdot \mathrm{x}_{2}^{2}, \\
\mathrm{CHC}_{10 \text { с }}=-688,074+11,27 \cdot \mathrm{x}_{2}-0,043 \cdot \mathrm{x}_{2}^{2}, \\
\mathrm{CHC}_{10 \text { мин }}=-791,852+13,237 \cdot \mathrm{x}_{2}-0,051 \cdot \mathrm{x}_{2}^{2},
\end{gathered}
$$

где $\mathrm{x}_{1}-$ концентрация формиата натрия, $\%$; $\mathrm{x}_{2}-$ температура, ${ }^{\circ} \mathrm{C}$.

\begin{tabular}{|c|c|c|c|c|c|}
\hline \multirow[b]{2}{*}{$\begin{array}{c}\text { Уровень варьируемых } \\
\text { факторов } \\
\text { Level of variable factors }\end{array}$} & \multirow{2}{*}{ 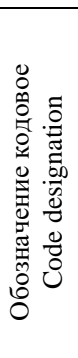 } & \multicolumn{2}{|c|}{$\begin{array}{c}\text { Показатель } \\
\text { фильтрации } \\
\text { API fl. loss }\end{array}$} & \multicolumn{2}{|c|}{$\begin{array}{c}\text { Реологические } \\
\text { параметры } \\
\text { Rheological } \\
\text { parameters }\end{array}$} \\
\hline & & 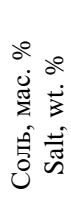 & 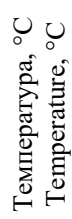 & 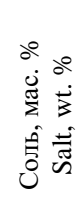 & 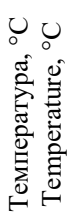 \\
\hline $\begin{array}{l}\text { Основной уровень } \\
\text { Main level }\end{array}$ & 0 & 72,9 & 100 & 72,9 & 130 \\
\hline $\begin{array}{l}\text { Интервал варьирования } \\
\text { Variation interval }\end{array}$ & $\Delta \mathrm{Xi}$ & 24,3 & 67,5 & 24,3 & 30 \\
\hline $\begin{array}{l}\text { Верхний уровень } \\
\text { Upper level }\end{array}$ & 1 & 97,2 & 160 & 97,2 & 160 \\
\hline $\begin{array}{l}\text { Нижний уровень } \\
\text { Lower level }\end{array}$ & -1 & 48,6 & 25 & 48,6 & 100 \\
\hline
\end{tabular}

Таблица 5. Значения варьируемых факторов для изучения их влияния на показатель фильтрации и реологические параметры глинистого крахмалсодержащего бурового раствора

Table 5. Values of variable factors for studying the filtration rate and rheological parameters of clay starch-containing drilling mud

Таблица 6. Матрица центрального композиционного планирования и результать определения показателя фильтрачии крахмалсодержащего бурового раствора через 16 часов старения при разных уровнях варьируемых факторов (кониентрации формиата натрия и темпе-

\begin{tabular}{|c|c|c|c|c|}
\hline $\begin{array}{c}\text { Место плана } \\
\text { Place of the } \\
\text { plan }\end{array}$ & $\begin{array}{c}\text { Номер } \\
\text { опыта } \\
\text { Experience } \\
\text { number }\end{array}$ & $\begin{array}{l}\text { Соль } \\
\left(\mathrm{X}_{1}\right) \\
\text { Salt } \\
\left(\mathrm{X}_{1}\right)\end{array}$ & $\begin{array}{c}\text { Tемпера- } \\
\text { тура }\left(\mathrm{X}_{2}\right) \\
\text { Temperatu } \\
\text { re }\left(\mathrm{X}_{2}\right)\end{array}$ & $\begin{array}{c}\text { ПФ, } \\
\text { мл/30мин } \\
\text { API fl. loss, } \\
\text { ml/30min }\end{array}$ \\
\hline \multirow{4}{*}{$\begin{array}{c}\text { Ядро плана } \\
\text { ПФЭ } 2^{2} \\
\text { Core of the } \\
\text { FFE } 2^{2} \text { plan }\end{array}$} & 1 & -1 & -1 & 17,0 \\
\hline & 2 & -1 & 1 & 7,0 \\
\hline & 3 & 1 & -1 & 25,0 \\
\hline & 4 & 1 & 1 & 5,0 \\
\hline \multirow{4}{*}{$\begin{array}{l}\text { Звездные } \\
\text { точки } \\
\text { Star points }\end{array}$} & 5 & -1 & 0 & 5,2 \\
\hline & 6 & 1 & 0 & 7,6 \\
\hline & 7 & 0 & -1 & 22,0 \\
\hline & 8 & 0 & 1 & 6,0 \\
\hline \multirow{2}{*}{$\begin{array}{l}\text { Центр плана } \\
\text { Plan center }\end{array}$} & 9 & 0 & 0 & 4,9 \\
\hline & 10 & 0 & 0 & 4,9 \\
\hline
\end{tabular}
ратуры)

Table 6. Matrix of central compositional planning and the results of determining the filtration rate of starch-containing drilling fluid at different levels of variable factors (sodium formate concentration and temperature) after 16 hours of temperature control 
Таблица 7. Матрица иентрального композиционного планирования и результаты определения реологических параметров крахмалсодержащего бурового раствора через 16 часов старения при разных уровнях варьируемых факторов (концентрации формиата натрия и температуры)

Table 7. Matrix of central compositional planning and the results of determining the rheological parameters of starch-containing drilling fluid at different levels of variable factors (concentration of sodium formate and temperature) after 16 hours of temperature control

\begin{tabular}{|c|c|c|c|c|c|c|c|}
\hline $\begin{array}{c}\text { Место плана } \\
\text { Place of the plan }\end{array}$ & 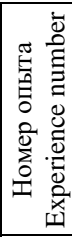 & 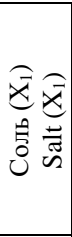 & 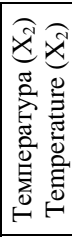 & 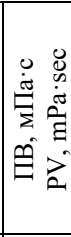 & 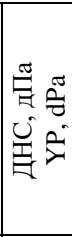 & 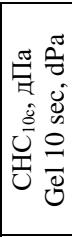 & 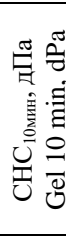 \\
\hline \multirow{4}{*}{$\begin{array}{l}\text { Ядро плана } \\
\text { ПФЭ } 2^{2} \\
\text { Core of the FFE } \\
2^{2} \text { plan }\end{array}$} & 1 & -1 & -1 & 14,7 & 40 & 13 & 20 \\
\hline & 2 & -1 & 1 & 16 & 43 & 14 & 19 \\
\hline & 3 & 1 & -1 & 18,3 & 30 & 10 & 25 \\
\hline & 4 & 1 & 1 & 26,5 & 62 & 14 & 19 \\
\hline \multirow{4}{*}{$\begin{array}{l}\text { Звездные точки } \\
\text { Star points }\end{array}$} & 5 & -1 & 0 & 18 & 130 & 57 & 71 \\
\hline & 6 & 1 & 0 & 32,3 & 136 & 71 & 92 \\
\hline & 7 & 0 & -1 & 16,3 & 51 & 14 & 20 \\
\hline & 8 & 0 & 1 & 22,8 & 55 & 18 & 22 \\
\hline \multirow{2}{*}{$\begin{array}{l}\text { Центр плана } \\
\text { Plan center }\end{array}$} & 9 & 0 & 0 & 26,6 & 110 & 38 & 52 \\
\hline & 10 & 0 & 0 & 26,6 & 110 & 38 & 52 \\
\hline
\end{tabular}

В полученные уравнения регрессии входят коэффициенты, статистическая вероятность которых больше 0,95 .

Адекватность математических моделей оценивали по критерию Фишера и коэффициенту детерминации, а также графическим методом - определяли область доверительного интервала при $\mathrm{p}=0,95$ и наносили на график фактически получаемые экспериментальные значения (рис. 1).

Как видим, во всех случаях: табличные значения $F$-критерия Фишера меньше расчетных; коэффициенты детерминации $R^{2}$, которые отражают меру качества регрессионной модели, описывающей изучаемый процесс, больше 0,80 ; графики предсказанных и наблюдаемых значений демонстрируют, что полученные модели хорошо описывают изучаемые явления. Следовательно, нулевые гипотезы о статистической незначимости каждого уравнения регрессии можно отвергнуть.

Воспользовавшись уравнением регрессии, которое описывает зависимость показателя фильтрации от изучаемых нами факторов, мы рассчитали его значения при разных концентрациях формиата натрия и разных температурах (табл. 8).

Из табл. 8 видно, что в области низких температур крахмалсодержащий буровой раствор, при любой концентрации формиата натрия, имеет высокие фильтрационные свойства, которые по мере увеличения степени нагрева системы начинают снижаться, достигают минимума, а затем вновь начинают расти. При этом минимальные значения показателя фильтрации с увеличением концентрации соли смещаются в область более высоких температур.
Анализ табличных данных показывает, что в зависимости от влияния концентрации формиата натрия на показатель фильтрации можно выделить три температурные области:

- $25-132{ }^{\circ} \mathrm{C}-\mathrm{c}$ увеличением концентрации соли показатель фильтрации увеличивается;

- $133{ }^{\circ} \mathrm{C}$ - при любых концентрациях соли показатель фильтрации имеет одно и то же значение;

- $134-160{ }^{\circ} \mathrm{C}-\mathrm{c}$ увеличением концентрации соли показатель фильтрации снижается.

Отсюда следует, что крахмалсодержащий буровой раствор имеет минимальные значения ПФ до $133{ }^{\circ} \mathrm{C}$ при минимальных концентрациях формиата натрия, после $133{ }^{\circ} \mathrm{C}$ - при насыщении системы солью (ячейки в таблице закрашены серым цветом); максимальные значения ПФ в таблице занимают зеркально расположенные позиции по отношению к минимальным значениям ПФ (значения в таблице выделены полужирным шрифтом).

Такая инверсия системы указывает на то, что механизмы снижения фильтрационных свойств крахмалсодержащего глинистого бурового раствора, в состав которого входит натриевая соль муравьиной кислоты, до и после $133^{\circ} \mathrm{C}$ различаются.

Повышение концентрации формиата натрия в составе крахмалсодержащего бурового раствора способствует загущению дисперсионной среды - гидратация соли приводит к связыванию большого количества молекул воды. Если предположить, что фильтрационные свойства крахмалсодержащего бурового раствора существенно зависят от вязкости дисперсионной среды, то с повышением концентрации соли в системе показатель фильтрации должен уменьшаться. Однако такую зависимость мы наблюдаем только после $133{ }^{\circ} \mathrm{C}$. Следовательно, после воздействия высоких температур в интервале $133-160{ }^{\circ} \mathrm{C}$ низкие значения показателя фильтрации являются в основном следствием связывания свободной воды формиатом натрия.

Противоположная картина в диапазоне температур до $133{ }^{\circ} \mathrm{C}$, по всей видимости, обусловлена высокой растворимостью соли, которая преобладает над растворимостью крахмала, в результате чего повышение концентрации формиата натрия уменьшает эффективность полисахарида как понизителя фильтрации. При этом негативное влияние натриевой соли муравьиной кислоты на полимер существенно в диапазоне низких температур; с повышением температуры оно снижается, и действенность полисахарида увеличивается.

Таким образом, в диапазоне температур $100-133{ }^{\circ} \mathrm{C}$ низкие фильтрационные свойства крахмалсодержащего бурового раствора обеспечиваются за счет эффективности полисахарида, при этом содержание формиата натрия должно быть в области низких концентраций; в диапазоне температур 133-160 ${ }^{\circ} \mathrm{C}$ система будет иметь минимальные значения показателя фильтрации за счет увеличения вязкости дисперсионной среды, т. е. при повышенных концентрациях соли. 


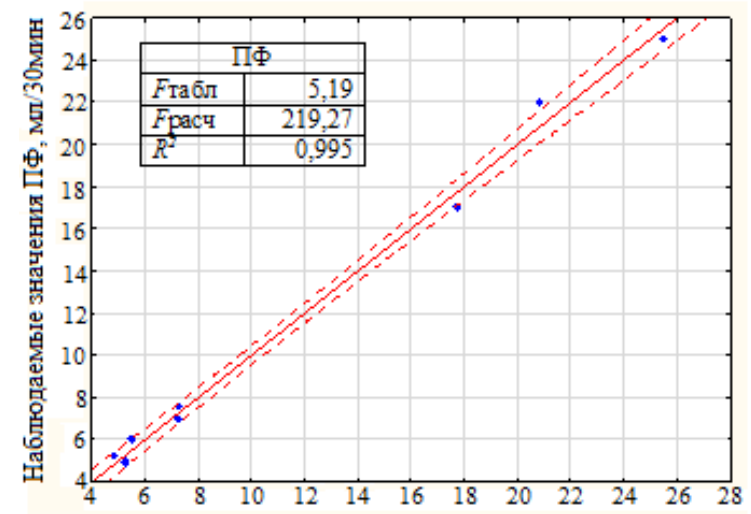

Предсказанные значения ПФ, мл/30 Mин $0.05 \mathrm{cminh}$
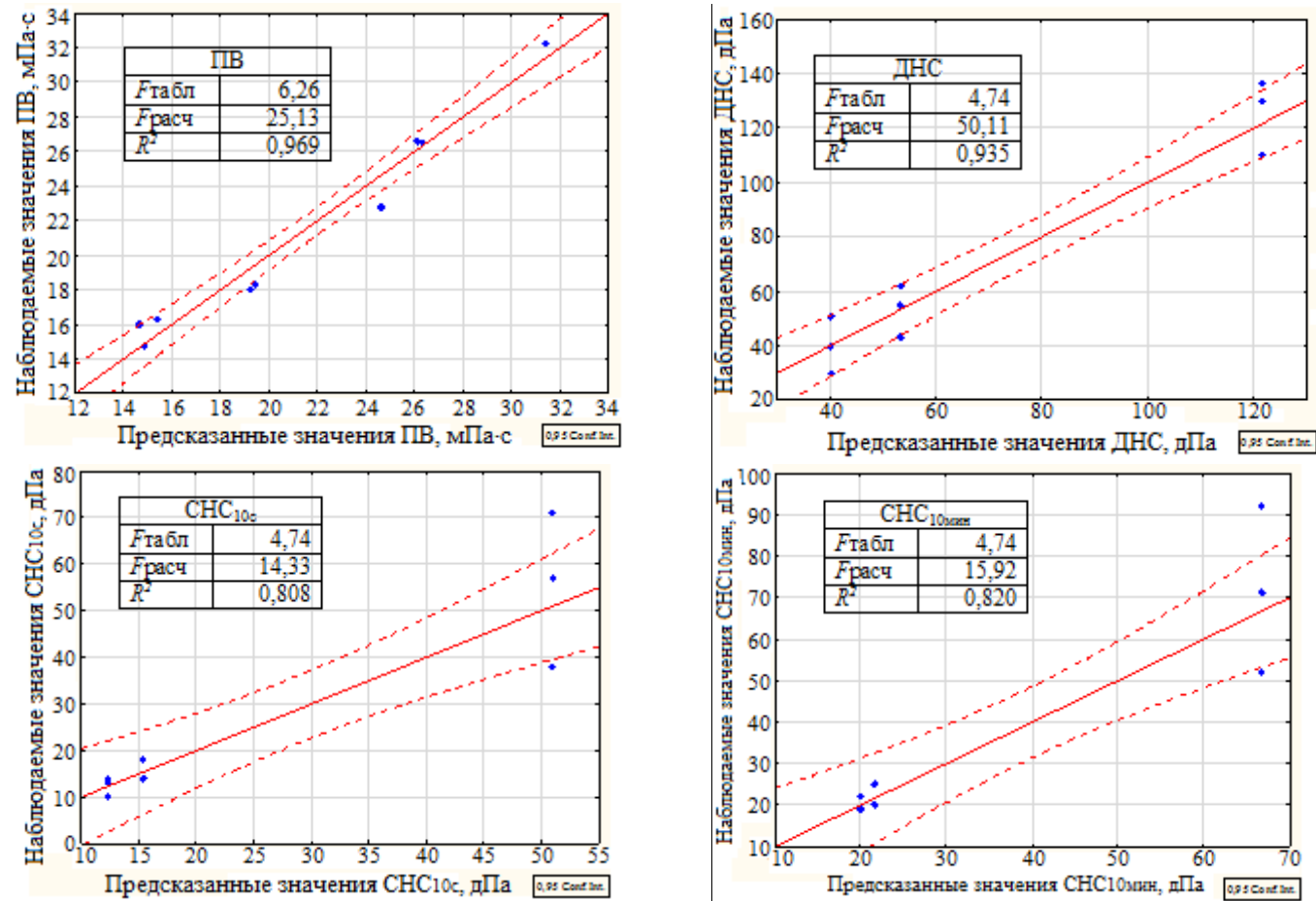

Рис. 1. Графики наблюдаемых и предсказанных по уравнениям регрессий значений показателя фильтраиии (ПФ) и реологических параметров (ПВ, ДНС, СНС $_{10 c}$ и СНС ${ }_{10 \text { мин) }}$ при доверительной вероятности р=0,95 (nунктирная линия - доверительный интервал)

Fig. 1. Graphs of the observed and predicted by the regression equations values of the API fl. loss and rheological parameters (PV, YP, Gel $l_{10 s e c}$, and $\mathrm{Gel}_{10 \mathrm{~min}}$ ) with a confidence probability of $p=0,95$ (dashed line - confidence interval)

Таблица 8. ПФ (мл/30 мин) крахмалсодержащего глинистого бурового раствора в температурном диапазоне $25-160^{\circ}$ С в зависимости от концентрации формиата натрия

Table 8. API fl. loss ( $\mathrm{ml} / 30 \mathrm{~min}$ ) of starch-containing clay mud in the temperature range of $25-160^{\circ} \mathrm{C}$ depending on the concentration of sodium formate

\begin{tabular}{|c|c|c|c|c|c|c|c|c|c|c|c|c|c|c|c|c|c|c|c|c|c|c|}
\hline & \multicolumn{10}{|c|}{ Температура/Temperature, ${ }^{\circ} \mathrm{C}$} \\
\hline $\begin{array}{c}\text { Соль } \\
\text { Salt, \% }\end{array}$ & 25 & 50 & 75 & 100 & 111 & 112 & 115 & 120 & 121 & 122 & 123 & 127 & 130 & 132 & 133 & 134 & 135 & 140 & 145 & 150 & 155 & 160 \\
\hline 48,6 & 17,3 & 11,1 & 6,8 & 4,4 & 4,1 & 4,0 & 4,0 & 4,0 & 4,0 & 4,0 & 4,1 & 4,2 & 4,3 & 4,4 & $\mathbf{4 , 4}$ & $\mathbf{4 , 5}$ & $\mathbf{4 , 5}$ & $\mathbf{4 , 9}$ & $\mathbf{5 , 3}$ & $\mathbf{5 , 8}$ & $\mathbf{6 , 3}$ & $\mathbf{7 , 0}$ \\
\hline 50 & 17,6 & 11,2 & 6,9 & 4,5 & 4,1 & 4,1 & 4,0 & 4,0 & 4,1 & 4,1 & 4,1 & 4,2 & 4,3 & 4,4 & $\mathbf{4 , 4}$ & 4,5 & 4,5 & 4,9 & 5,3 & 5,7 & 6,3 & 6,9 \\
\hline 55 & 18,4 & 11,9 & 7,3 & 4,8 & 4,3 & 4,2 & 4,2 & 4,1 & 4,2 & 4,2 & 4,2 & 4,2 & 4,3 & 4,4 & $\mathbf{4 , 4}$ & 4,5 & 4,5 & 4,8 & 5,2 & 5,6 & 6,1 & 6,7 \\
\hline 60 & 19,2 & 12,5 & 7,8 & 5,0 & 4,4 & 4,4 & 4,3 & 4,2 & 4,2 & 4,2 & 4,2 & 4,3 & 4,3 & 4,4 & $\mathbf{4 , 4}$ & 4,5 & 4,5 & 4,8 & 5,1 & 5,5 & 6,0 & 6,5 \\
\hline 65 & 20,0 & 13,1 & 8,2 & 5,3 & 4,6 & 4,6 & 4,5 & 4,3 & 4,3 & 4,3 & 4,3 & 4,3 & 4,4 & 4,4 & $\mathbf{4 , 4}$ & 4,5 & 4,5 & 4,7 & 5,0 & 5,4 & 5,8 & 6,3 \\
\hline 70 & 20,9 & 13,8 & 8,6 & 5,5 & 4,8 & 4,7 & 4,6 & 4,4 & 4,4 & 4,4 & 4,4 & 4,4 & 4,4 & 4,4 & $\mathbf{4 , 4}$ & 4,5 & 4,5 & 4,6 & 4,9 & 5,2 & 5,6 & 6,1 \\
\hline 75 & 21,7 & 14,4 & 9,1 & 5,8 & 4,9 & 4,9 & 4,7 & 4,5 & 4,5 & 4,5 & 4,5 & 4,4 & 4,4 & 4,4 & $\mathbf{4 , 4}$ & 4,4 & 4,5 & 4,6 & 4,8 & 5,1 & 5,5 & 5,9 \\
\hline 80 & 22,5 & 15,0 & 9,5 & 6,0 & 5,1 & 5,0 & 4,9 & 4,6 & 4,6 & 4,6 & 4,6 & 4,5 & 4,4 & 4,4 & $\mathbf{4 , 4}$ & 4,4 & 4,5 & 4,5 & 4,7 & 5,0 & 5,3 & 5,7 \\
\hline 85 & 23,3 & 15,7 & 10,0 & 6,3 & 5,3 & 5,2 & 5,0 & 4,7 & 4,7 & 4,7 & 4,6 & 4,5 & 4,5 & 4,4 & $\mathbf{4 , 4}$ & 4,4 & 4,4 & 4,5 & 4,6 & 4,8 & 5,1 & 5,5 \\
\hline 90 & 24,2 & 16,3 & 10,4 & 6,5 & 5,4 & 5,4 & 5,2 & 4,9 & 4,8 & 4,8 & 4,7 & 4,6 & 4,5 & 4,5 & $\mathbf{4 , 4}$ & 4,4 & 4,4 & 4,4 & 4,5 & 4,7 & 5,0 & 5,3 \\
\hline 95 & 25,0 & 16,9 & 10,9 & 6,8 & 5,6 & 5,5 & 5,3 & 5,0 & 4,9 & 4,8 & 4,8 & 4,6 & 4,5 & 4,5 & $\mathbf{4 , 4}$ & 4,4 & 4,4 & 4,4 & 4,4 & 4,6 & 4,8 & 5,1 \\
\hline 97,2 & $\mathbf{2 5 , 3}$ & $\mathbf{1 7 , 2}$ & $\mathbf{1 1 , 1}$ & $\mathbf{6 , 9}$ & $\mathbf{5 , 7}$ & $\mathbf{5 , 6}$ & $\mathbf{5 , 4}$ & $\mathbf{5 , 0}$ & $\mathbf{4 , 9}$ & $\mathbf{4 , 9}$ & $\mathbf{4 , 8}$ & $\mathbf{4 , 6}$ & $\mathbf{4 , 5}$ & $\mathbf{4 , 5}$ & $\mathbf{4 , 4}$ & 4,4 & 4,4 & 4,4 & 4,4 & 4,5 & 4,7 & 5,0 \\
\hline
\end{tabular}


Рост показателя фильтрации с повышением температуры свидетельствует о деструкции крахмального полимера, при этом с увеличением концентрации формиата натрия повышение фильтрационных свойств начинается при более высоких температурах. Отсюда следует, что натриевая соль муравьиной кислоты влияет на термостойкость полисахарида - из-за высокой растворимости формиат натрия подавляет гидратацию крахмала, вследствие чего снижается возможность его интенсивного гидролиза при воздействии высоких температур. Таким образом, термостойкость крахмала напрямую зависит от концентрации формиата натрия - с увеличением содержания соли в системе повышается температура деструкции полисахарида.

Диаграмма, представленная на рис. 2, показывает, что для каждой температуры есть своя оптимальная концентрация формиата натрия, при которой крахмалсодержащий буровой раствор будет иметь минимальные фильтрационные свойства, при этом видно, что с увеличением температуры требуемая концентрация соли увеличивается и необходимость насыщения системы солью возникает при использовании ее в диапазоне 140-141 $\mathrm{C}$. Следовательно, крахмалсодержащий буровой раствор, насыщенный формиатом натрия, будет иметь низкие значения показателя фильтрации при эксплуатации его в интервале температур $140-141^{\circ} \mathrm{C}$.

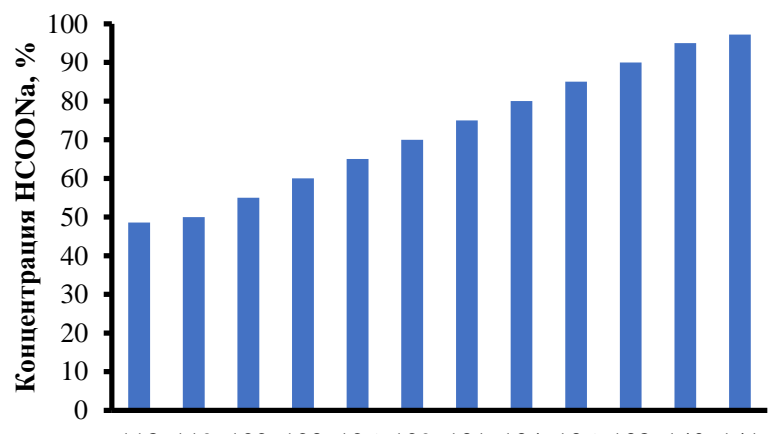

$118119122 \quad 123 \quad 126 \quad 129131 \quad 134136138 \quad 140141$

\section{Температура, ${ }^{\circ} \mathrm{C}$}

Pис. 2. Оптимальная концентрация формиата натрия, рекомендуемая для каждой температуры, при которой показатель фильтрачии крахмалсодежащего бурового раствора имеет минимальные значения (4,0-4,4 мл/30 мин)

Fig. 2. Optimal concentration of sodium formate, recommended for each temperature, at which the filtration rate of starch-containing drilling fluid has a minimum value $(4,0-4,4 \mathrm{ml} / 30 \mathrm{~min})$

Ранее мы предполагали, что одним из механизмов повышения термостойкости крахмального полимера может быть сшивка его формиатом натрия в условиях высоких температур. Если предположить, что это так, то соль муравьиной кислоты должна оказывать существенное влияние на реологические параметры.

Анализ математических моделей, описывающих структурно-механические свойства крахмалсодержащего глинистого бурового раствора (ДНС и СНС) показывает, что они зависят только от температуры и абсолютно не зависят от концентрации соли, при этом графические зависимости ДНС $=f(\mathrm{~T}), \mathrm{CHC}_{10 c}=f(\mathrm{~T})$ и $\mathrm{CHC}_{10 м и н}=f(\mathrm{~T})$ (рис. 3) характеризуют процессы пептизации глины при воздействии повышенных температур. Значит, наше предположение о том, что формиат натрия каким-то образом изменяет форму взаимодействий между полимерными цепями крахмала или способствует их сшивке можно опровергнуть.

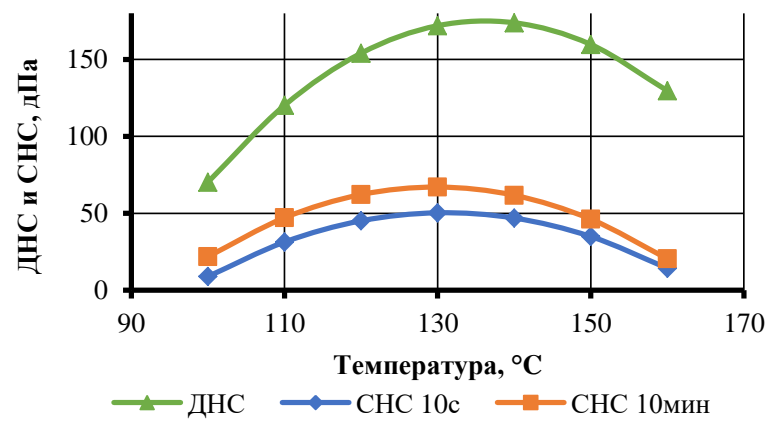

Pис. 3. Воздействие температуры на реологические параметры (ДНС и СНС) бурового раствора

Fig. 3. Effect of temperature on the rheological parameters (YP and Gel) of the drilling fluid

Существенно влияние изучаемых нами факторов на пластическую вязкость крахмалсодержащего бурового раствора (табл. 9). С увеличением концентрации формиата натрия пластическая вязкость повышается, а с увеличением температуры - подобно ДНС и CHC - вначале растет, достигает в некотором температурном интервале максимальных значений, а затем падает. Однако для каждой концентрации соли муравьиной кислоты характерен свой температурный диапазон, при котором пластическая вязкость имеет максимальные значения (ячейки в таблице закрашены серым цветом) - с повышением концентрации формиата натрия он увеличивается и достигает максимальных значений при 65-70 \% соли; дальнейшее увеличение концентрации формиата натрия приводит к его снижению.

Такая параболическая зависимость от концентрации формиата натрия температур, при которых крахмалсодержащая система имеет максимальные значения пластической вязкости, по всей видимости, связана с дополнительным к температуре пептизирующим действием соли на глину. С увеличением концентрации формиата натрия, под действием гидроксид-ионов, глинистые частицы вначале начинают разъединяться, но толщина двойного электрического слоя (ДЭС) на их поверхности еще мала и трение между ними существенно, поэтому пластическая вязкость увеличивается и достигает максимальных значений при 65-70 \% соли муравьиной кислоты; дальнейшее увеличение концентрации соли в системе способствует растяжению ДЭС, а также существенному увеличению вязкости дисперсионной среды, поэтому количество контактирующих центров между глинистыми частицами снижается - пластическая вязкость системы падает. 
Таблица 9. ПВ (мПа.с) крахмалсодержащего глинистого бурового раствора в зависимости от конщентрации формиата натрия в температурном диапазоне $100-160^{\circ} \mathrm{C}$

Table 9. Plastic viscosity $P V(\mathrm{mPa} \cdot \mathrm{s})$ of starch-containing clay mud depending on the concentration of sodium formate in the temperature range of $100-160^{\circ} \mathrm{C}$

\begin{tabular}{|c|c|c|c|c|c|c|c|c|c|c|c|c|c|c|c|c|c|c|c|c|c|c|}
\hline & \multicolumn{110}{|c|}{ Температура/Temperature, ${ }^{\circ} \mathrm{C}$} \\
\hline $\begin{array}{c}\text { Cоль, \% } \\
\text { Salt, \% }\end{array}$ & 100 & 120 & 125 & 127 & 129 & 130 & 131 & 132 & 133 & 134 & 136 & 137 & 138 & 139 & 140 & 141 & 142 & 143 & 144 & 145 & 150 & 160 \\
\hline 48,6 & 14,8 & 18,7 & 19,1 & 19,1 & 19,2 & 19,2 & 19,2 & 19,1 & 19,1 & 19,1 & 19,0 & 18,9 & 18,8 & 18,7 & 18,6 & 18,5 & 18,4 & 18,3 & 18,2 & 18,0 & 17,1 & 14,6 \\
\hline 50 & 14,8 & 19,0 & 19,4 & 19,5 & 19,6 & 19,6 & 19,6 & 19,6 & 19,6 & 19,6 & 19,5 & 19,4 & 19,4 & 19,3 & 19,2 & 19,1 & 19,0 & 18,9 & 18,8 & 18,6 & 17,8 & 15,4 \\
\hline 55 & 14,6 & 20,1 & 20,7 & 20,9 & 21,1 & 21,2 & 21,2 & 21,3 & 21,3 & 21,3 & 21,3 & 21,3 & 21,3 & 21,2 & 21,2 & 21,1 & 21,1 & 21,0 & 20,9 & 20,8 & 20,1 & 18,0 \\
\hline 60 & 14,6 & 21,1 & 22,0 & 22,3 & 22,5 & 22,6 & 22,7 & 22,8 & 22,9 & 22,9 & 23,0 & 23,0 & 23,0 & 23,0 & 23,0 & 23,0 & 22,9 & 22,9 & 22,8 & 22,8 & 22,2 & 20,3 \\
\hline 65 & 14,8 & 22,2 & 23,3 & 23,6 & 23,9 & 24,0 & 24,1 & 24,3 & 24,3 & 24,4 & 24,5 & 24,6 & 24,6 & 24,6 & 24,6 & 24,6 & 24,6 & 24,6 & 24,6 & 24,5 & 24,0 & 22,2 \\
\hline 70 & 15,1 & 23,3 & 24,5 & 24,9 & 25,2 & 25,4 & 25,5 & 25,6 & 25,7 & 25,8 & 26,0 & 26,0 & 26,1 & 26,1 & 26,1 & 26,1 & 26,1 & 26,1 & 26,1 & 26,0 & 25,6 & 23,8 \\
\hline 75 & 15,6 & 24,3 & 25,6 & 26,1 & 26,4 & 26,6 & 26,8 & 26,9 & 27,0 & 27,1 & 27,3 & 27,4 & 27,4 & 27,5 & 27,5 & 27,5 & 27,5 & 27,5 & 27,4 & 27,4 & 26,9 & 25,0 \\
\hline 80 & 16,2 & 25,4 & 26,8 & 27,2 & 27,6 & 27,8 & 27,9 & 28,1 & 28,2 & 28,3 & 28,5 & 28,5 & 28,6 & 28,6 & 28,6 & 28,7 & 28,6 & 28,6 & 28,6 & 28,5 & 28,0 & 25,9 \\
\hline 85 & 16,9 & 26,5 & 27,9 & 28,3 & 28,7 & 28,9 & 29,0 & 29,2 & 29,3 & 29,4 & 29,5 & 29,6 & 29,6 & 29,7 & 29,7 & 29,7 & 29,6 & 29,6 & 29,5 & 29,5 & 28,8 & 26,4 \\
\hline 90 & 17,8 & 27,6 & 29,0 & 29,4 & 29,8 & 29,9 & 30,1 & 30,2 & 30,3 & 30,4 & 30,5 & 30,5 & 30,5 & 30,5 & 30,5 & 30,5 & 30,4 & 30,4 & 30,3 & 30,2 & 29,4 & 26,6 \\
\hline 95 & 18,8 & 28,7 & 30,0 & 30,4 & 30,7 & 30,9 & 31,0 & 31,1 & 31,2 & 31,2 & 31,3 & 31,3 & 31,3 & 31,3 & 31,2 & 31,2 & 31,1 & 31,0 & 30,8 & 30,7 & 29,7 & 26,4 \\
\hline 97,2 & 19,3 & 29,2 & 30,5 & 30,8 & 31,1 & 31,3 & 31,4 & 31,5 & 31,5 & 31,6 & 31,6 & 31,6 & 31,6 & 31,5 & 31,5 & 31,4 & 31,3 & 31,2 & 31,0 & 30,9 & 29,8 & 26,2 \\
\hline
\end{tabular}

Таким образом, анализ уравнений регрессий показывает, что реологические параметры испытуемого раствора, в первую очередь, зависят от температуры, увеличение которой интенсифицирует процессы пептизации глины; формиат натрия также оказывает пептизирующее действие на глину, но его влияние здесь вторично.

Последнее, что хотелось бы отметить, - это значение временного фактора на свойства тестируемой системы при нахождении его в области высоких температур. Если сравнить результаты испытаний растворов с одной и той же концентрацией соли и одинаковой температурой старения, но с разной продолжительностью нагрева, то можно увидеть, что временной фактор имеет большое значение. Так, раствор, содержащий 48,6 \% формиата натрия после нахождения при $160{ }^{\circ} \mathrm{C}$ в течение 16 часов имеет параметры: $\Pi \Phi=7$ мл $/ 30$ мин, ПВ=16 мПа.с, ДНС=43 дПа, $\mathrm{CHC}_{10 \mathrm{c} / 10 \text { мин }}=14 / 19$ дПа (табл. 6, 7); после 32 часов термостарения - ПФ=19 мл/30 мин, ПВ=24,3 мПа.с, ДНС=42 дПа, $\mathrm{CHC}_{10 \mathrm{c} / 10 \text { мин }}=19 / 23$ дПа (табл. 3). Как видно, фильтрационные свойства с увеличением времени воздействия повышенных температур возрастают, что указывает на значительную степень деструкции полисахарида. Изменения претерпевают также и реологические параметры. Следовательно, длительность нахождения системы при повышенных температурах тоже оказывает влияние на свойства крахмалсодержащего раствора, в состав которого входит формиат натрия.

Таким образом, проведенные исследования показали, что термостойкость крахмального реагента при совместном применении с формиатом натрия повышается вследствие высокой растворимости соли, которая подавляет гидратацию полисахарида, и соответственно, замедляет его гидролиз при воздействии высоких температур. С увеличением температуры доминирующее влияние формиата натрия над полимером ослабевает и его действенность, как понизителя фильтрации, до некоторой температуры увеличивается. Низкие значения показателя фильтрации крахмалсодержащего раствора, в состав которого входит натриевая соль муравьиной ксилоты, после термостарения в интервале $100-133{ }^{\circ} \mathrm{C}$ обеспечива- ются эффективностью полисахарида при минимальных концентрациях соли, в интервале $133-160{ }^{\circ} \mathrm{C}-$ повышенной концентрацией формиата натрия, который уменьшает содержание свободной воды в системе за счет своей высокой растворимости. В силу указанных причин эффективность применения формиата натрия в составе испытуемой системы ограничивается концентрацией соли и рабочим диапазоном температур. Также установлено, что с увеличением времени воздействия высоких температур степень термодеструкции крахмального полисахарида повышается.

Анализ математических моделей, описывающих реологические параметры крахмального глинистого раствора с формиатом натрия, позволил нам предположить, что натриевая соль муравьиной кислоты не предотвращает набухание глин, а наоборот, оказывает на них пептизирующее действие.

\section{Выводы}

1. Показано, что природа соли оказывает значительное влияние на термостойкость крахмалсодержащего бурового раствора.

2. Получены уравнения регрессии второго порядка, описывающие зависимость показателя фильтрации и реологических параметров крахмалсодержащего бурового раствора от температуры и концентрации формиата натрия. Адекватность математических моделей подтверждена критерием Фишера, коэффициентом детерминации, а также графическим методом.

3. Установлено, что термостойкость крахмального реагента при совместном применении с формиатом натрия повышается вследствие высокой растворимости соли, которая подавляет гидратацию полисахарида, и соответственно, замедляет его гидролиз при воздействии высоких температур;

4. Экспериментально определено, что с увеличением времени воздействия температуры степень деструкции крахмального полимера возрастает.

5. Выявлено, что эффективная концентрация натриевой соли муравьиной кислоты как термостабилизатора в составе крахмалсодержащего бурового раствора зависит от температуры применения си- 
стемы. Низкие значения показателя фильтрации после термостарения в интервале $100-133{ }^{\circ} \mathrm{C}$ обеспечиваются эффективностью полисахарида при минимальном содержании соли, в интервале 133-160 ${ }^{\circ} \mathrm{C}$ - повышенной концентрацией формиата натрия, который уменьшает содержание

\section{СПИСОК ЛИТЕРАТУРЫ}

1. High temperature drilling fluid component: Patent 4652384 USA. Fil. 30.08.1984; Publ. 24.03.1987.

2. Influence of monoethanolamine on thermal stability of starch in water based drilling fluid system / Nasiri Alireza, Mohammad Javad Ameri Shahrabi, Mohammad Amin Sharif Nik, Hamidreza Heidari, Majid Valizadeh // Petroleum Exploration and Development. - 2018. - V. 45. - P. 167-171.

3. Повышение термостойкости полисахаридов, применяемых в буровых промывочных жидкостях / Р.Р. Ахаев, С.Ф. Вязниковцев, О.Г. Мамаева, Т.Д. Дихтярь // Современные технологии в нефтегазовом деле - 2017 сборник трудов международной научно-технической конференции. В 2-х т. - Уфа: Изд-во УГНТУ, 2017. - Т. 1 - С. 226-229

4. Ахаев Р.Р., Мамаева О.Г. Термостойкость минерализованных буровых растворов, содержащих полисахариды // Нефтегазовый комплекс: проблемы и инновации тезисы II научнопрактической конференции с международным участием / Отв. ред. В.К. Тян. - Самара: Самар. гос. техн. ун-т, 2018. - С. 69.

5. Городнов В.Д. Физико-химические методы предупреждения осложнений в бурение. 2-е изд. перераб. и доп. - М.: Недра, 1984. - C. 91-101.

6. Исследование глин и новые рецептуры растворов / В.Д. Городнов, В.Н. Тесленко, П.И. Колесников, Б.К. Челомбиев. М.: Недра, 1971. -204 c.

7. Rheological characterisation of xanthan gum in brine solutions at high temperature / D. Reinoso, M.J. Martín-Alfonso, P.F. Luckham, F.J. Martínez-Boza // Carbohydrate Polymers. 2018. - V. 03. - P. 103-109.

8. Черевко С.А., Хомутов А.Ю., Сыроегин М.А., Королев А.В., Попов С.В., Луковкин Ю.В. Применение безбаритовой системы бурового раствора UNIFORM K на основе формиата калия при строительстве горизонтальной скважины на продуктивный пласт «АС» Южно-Приобского месторождения // Бурение \& нефть. - 2017. - № 7/8 - С. 48-53.

9. Davarpanah A., Mirshekari B. Effect of formate fluids on shale stabilization of shale layers // Energy Reports. - 2019. - V. 5. P. 987-992.

10. Утяжеленный буровой раствор: пат. Рос. Федерация, № 2700132, заявл. 09.01.2019; опубл. 12.09.2019. Бюл. № 26. - 8 c. свободной воды в системе за счет своей высокой растворимости.

6. Показано, что формиат натрия не предотвращает набухание глин, а наоборот, способен оказывать на них пептизирующее действие.

11. The Evolution and application of formate brines in hightemperature/high-pressure operations / D. Bungert, S. Maikranz, R. Sundermann, J. Down, W. Benton, M.A. Dick // IADC/SPE Drilling Conference. - New Orleans, Louisiana, February 23-25, 2000. - P. 1-11.

12. Oswald R.J., Knox D.A., Monem, M.R. Taking nondamaging fluids to new extremes: formate-based drilling fluids for hightemperature reservoirs in Pakistan // SPE International Symposium and Exhibition on Formation Damage Control. - Lafayette, Louisiana, USA, 15-17 February, 2006. - P. 1-9.

13. Утяжеленный минерализованный безглинистый буровой раствор: пат. Рос. Федерация, № 2655276, заявл. 29.03.2017; опубл. 24.05.2018. Бюл. № 15. - 8 с.

14. Утяжеленный минерализованный буровой раствордля вскрытия продуктивных пластов с аномально высоким пластовым давлением: пат. Рос. Федерация, № 2683448, заявл. 12.02.2014; опубл. 28.03.2018. Бюл. № 10. -9 c.

15. Formate Manual, Section A1; Chemistry // Version 3 ed. M.A. USA: Cabot Corporation. 2011. URL: https://www.formatebrines. $\mathrm{com} / \mathrm{manual} /$ (дата обращения 15.12.2019).

16. Howard S., Downs J. Formate fluids optimize production rate // AADE 2005 National Technical Conference and Exhibition. Houston, Texas, USA, 5-7 April, 2005. - P. 1-10.

17. Caenn R., Darley H.C.H., Gray G.R. Composition and properties of drilling and completion fluids. 6th ed. - US: Gulf Publishing Company, 2011. $-720 \mathrm{p}$.

18. Howard S., Downs J. Formate brines for HP/HT well control: new insights into the role and importance of the carbonate/bicarbonate additive package // SPE International Symposium on Oilfield Chemistry. - Texas, 2009. - P. 1-12.

19. ГОСТ 33213-2014 (ISO 10414-1:2008). Контроль параметров буровых растворов в промысловых условиях. Растворы на водной основе. - М.: Стандартинформ, 2015. - 75 с.

20. Халафян А.А. Промышленная статистика: контроль качества, анализ процессов, планирование экспериментов в пакете STATISTICA. - М.: Книжный дом «ЛИБРОКОМ», 2013. $384 \mathrm{c}$

Поступила 17.06.2020 2.

\section{Информация об авторах}

Конесев Г.В., доктор технических наук, профессор кафедры бурения нефтяных и газовых скважин Уфимского государственного нефтяного технического университета.

Axaев P.P., аспирант Уфимского государственного нефтяного технического университета.

Дихтярь T.Д., кандидат технических наук, доцент кафедры разведки и разработки нефтяных и газовых месторождений филиала Уфимского государственного нефтяного технического университета в г. Октябрьском.

Мамева О.Г., кандидат технических наук, доцент кафедры бурения нефтяных и газовых скважин Уфимского государственного нефтяного технического университета.

Вязниковцев С.Ф., соискатель Уфимского государственного нефтяного технического университета. 
UDC 622.24.063.2

\title{
RESEARCH OF THE SODIUM FORMATE INFLUENCE ON THERMOSTABILITY OF STARCH-CONTAINING CLAY DRILLING MUD
}

\author{
Gennady V. Konesev 1 , \\ KonesevGV@mail.ru \\ Rustam R. Akhaev ${ }^{1}$, \\ unixru@mail.ru
}

Tatyana D. Dikhtyar2,
dihttd@gmail.com

Oksana G. Mamaeva', oxana.mamaeva2013@yandex.ru

\author{
Sergey F. Vyaznikovtsev ${ }^{1}$, \\ kontakt-sintez@yandex.ru \\ 1 Ufa State Petroleum Technical University, \\ 1, Kosmonavtov street, Ufa, 450062, Russia. \\ 2 Ufa State Petroleum Technical University in the City of Oktyabrsky, \\ 54, Devonskaya street, Oktyabrsky, 452620, Russia.
}

The relevance of the work is caused by the need to preserve the properties of drilling fluids containing starchy reagents, in conditions of high salinity and prolonged exposure to elevated temperatures.

The main aim of the study is to determine experimentally the temperature range and optimal concentrations of the effective use of sodium formate in drilling fluids containing starch reagents.

The objects: starch-containing clay mud with different concentrations of sodium salts (sodium chloride and sodium formate).

Methods: determination of filtration and rheological parameters according to GOST 33213-2014 (ISO 10414-1: 2008) after drilling fluids aging at elevated temperatures using thermal cells; conducting experiments by constructing a matrix of central compositional planning and mathematical processing of the results of experimental data.

Results. The authors have carried out thecomparative analysis of the properties of clay drilling fluids containing starch reagent, using sodium chloride $\mathrm{NaCl}$ and sodium formate $\mathrm{HCOONa}$, after a long stay of the system at high temperatures. It is shown that the nature of the salt has a significant effect on the heat resistance of starch-containing drilling fluid: sodium chloride does not provide thermostability of the solution; sodium formate allows providing heat resistance starch-containing drilling fluid to $140-160{ }^{\circ} \mathrm{C}$. The second-order regression equations were obtained. They describe the dependence of the filtration rate and rheological parameters of starch-containing clay mud on the temperature and concentration of sodium formate. It was found that the heat resistance of starch reagent when combined with sodium formate increases due to the high solubility of the salt, which inhibits the polysaccharide hydration, and, accordingly, slows down its hydrolysis when exposed to high temperatures. It was revealed that the effective concentration of sodium salt of formic acid as a heat stabilizer in the composition of starch-containing drilling fluid depends on the temperature of application of the system: at low salt concentrations, heat resistance is ensured in the range of $100-133^{\circ} \mathrm{C}$ due to good starch activity; at high salt concentrations - in the range $133-160^{\circ} \mathrm{C}$ - due to the low content of free water in the system due to the high solubility of sodium formate. It was shown that sodium formate does not prevent clay swelling, but, on the contrary, is capable of exerting a peptizing effect on them.

Key words: Polysaccharide, destruction, heat resistance, mineralization, formate, drilling mud, salt, starch.

\section{REFERENCES}

1. Francis H.P., DeBoer E.D., Wermers V.L. High temperature drilling fluid component: Patent 4652384A USA, 1987.

2. Nasiri Alireza, Mohammad Javad Ameri Shahrabi, Mohammad Amin Sharif Nik, Hamidreza Heidari, Majid Valizadeh. Influence of monoethanolamine on thermal stability of starch in water based drilling fluid system. Petroleum Exploration and Development, 2018, vol. 45, pp. 167-171.

3. Akhaev R.R., Vyaznikovtsev S.F., Mamaeva O.G., Dikhtyar T.D Termostoykost mineralizovannykh burovykh rastvoro, soderzhashchikh polisakharidy [Improving the heat resistance of polysaccharides used in drilling drilling fluids]. Sovremennye tekhnologii $v$ neftegazovom dele-2017 sbornik trudov mezhdunarodnoy nauchno-tekhnicheskoy konferentsii [Modern technologies in the oil and gas business-2017. Proc. of the international scientific and technical conference]. Ufa, USPTU Publ., 2017. Vol. 1, pp. 226-229.

4. Akhaev R.R., Mamaeva O.G. Povyshenie termostoykosti polisakharidov, primenyayemykh $\mathrm{v}$ burovykh promyvochnykh zhidkostyakh [The heat resistance of mineralized drilling fluids containing polysaccharides]. Neftegazovyy kompleks: problemy $i$ innovatsii. Tezisy II nauchno-prakticheskoy konferentsii $s$ mezhdunarodnym uchastiyem [Oil and gas complex: problems and innovations. Theses of the II scientific-practical conference with international participation]. Samara, Samara State Technical University, 2018. pp. 69.

5. Gorodnov V.D. Fiziko-khimicheskie metody preduprezhdeniya oslozhneniy $v$ bureniye. 2-e izd. pererab. i dop. [Physico-chemical methods for preventing complications in drilling. $2^{\text {nd }}$ ed. reslave. and add]. Moscow, Nedra Publ., 1984. pp. 91-101.

6. Gorodnov V.D., Teslenko V.N., Kolesnikov P.I., Chelombiev B.K. Issledovanie glin i novye retseptury rastvorov [Clay research and new solution formulations]. Moscow, Nedra Publ., 1971. 204 p.

7. Reinoso D., Martín-Alfonso M.J., Luckham P.F., Martínez-Boza F.J., Rheological characterisation of xanthan gum in brine solutions at high temperature. Carbohydrate Polymers, 2018, vol. 03, pp. 103-109.

8. Cherevko S.A., Khomutov A.Yu., Syroegin M.A., Korolev A.V., Popov S.V., Lukovkin Yu.V. The use of a barite-free UNIFORM 
$\mathrm{K}$ mud system based on potassium formate in the construction of a horizontal well on the AS production layer of the South Priobskoye field. Drilling \& Oil, 2017, no. 7/8, pp. 48-53. In Rus.

9. Davarpanah A., Mirshekari B. Effect of formate fluids on shale stabilization of shale layers. Energy Reports, 2019, vol. 5, pp. 987-992.

10. Kurbanov Y.M. Utyazhelenny burovoy rastvor [Weighted drilling mud]. Patent RF no. 2700132, 2019.

11. Bungert D., Maikranz S., Sundermann R., Down J., Benton W. and Dick M.A. The evolution and application of formate brines in high-temperature/high-pressure operations. IADC/SPE Drilling Conference. New Orleans, Louisiana, February 23-25, 2000. pp. 1-11.

12. Oswald R.J., Knox D.A., Monem M.R. Taking nondamaging fluids to new extremes: formate-based drilling fluids for hightemperature reservoirs in Pakistan. SPE International Symposium and Exhibition on Formation Damage Control. Lafayette, Louisiana, USA, 15-17 February, 2006. pp. 1-9.

13. Senyushkin S.V. Utyazhelenny mineralizovanny bezglinisty burovoy rastvor [Weighted mineralized clay-free drilling mud]. Patent RF no. 2655276, 2018

14. Senyushkin S.V. Utyazhelenny mineralizovanny burovoy rastvor dlya vskrytiya produktivnykh plastov s anomalno vysokim plastovym davleniyem [Weighted mineralized drilling mud for opening productive formations with abnormally high reservoir pressure]. Patent RF no. 2683448, 2018.
15. Formate Manual, Section A1; Chemistry. Version 3 ed. M.A. USA Cabot Corporation. 2011. Available at: https://www.formatebrines. com/manual/ (accessed 15 December 2019).

16. Howard S., Downs J. Formate fluids optimize production rate. AADE 2005 National Technical Conference and Exhibition. Houston, Texas, USA, 5-7 April, 2005. pp. 1-10.

17. Caenn R., Darley H.C.H., Gray G.R. Composition and Properties of Drilling and Completion Fluids. $6^{\text {th }}$ ed. USA, Gulf Publishing Company, 2011. $720 \mathrm{p}$.

18. Howard S., Downs J. Formate brines for HP/HT well control: new insights into the role and importance of the carbonate/bicarbonate additive package. SPE International Symposium on Oilfield Chemistry. Texas, 2009. pp. 1-12.

19. GOST 33213-2014 (ISO 10414-1: 2008). Kontrol parametrov burovykh rastvorov $v$ promyslovykh usloviyakh. Rastvory na vodnoy osnove [State Standard 33213-2014 (ISO 10414-1: 2008). Control of drilling fluid parameters in field conditions. Water based solutions]. Moscow, Standartinform Publ., 2015.75 p.

20. Khalafyan A.A. Promyshlennaya statistika: kontrol kachestva, analiz protsessov, planirovanie eksperimentov $v$ pakete STATISTICA [Industrial statistics: quality control, process analysis, experiment planning in the STATISTICA package]. Moscow, LIBROCOM Publ., 2013. 384 p.

Received: 17 June 2020.

\section{Information about the authors}

Gennady V. Konesev, Dr. Sc., professor, Ufa State Petroleum Technical University.

Rustam R. Akhaev, graduate student, Ufa State Petroleum Technical University.

Tatyana D. Dikhtyar, Cand Sc., associate professor, Ufa State Petroleum Technical University in the City of Oktyabrsky.

Oksana G. Mamaeva, Cand Sc., associate professor, Ufa State Petroleum Technical University.

Sergey F. Vyaznikovtsev, applicant, Ufa State Petroleum Technical University. 